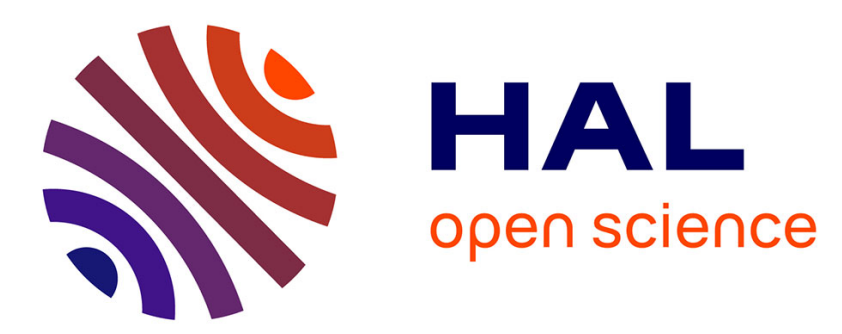

\title{
Bioaccumulation of cadmium, copper and zinc in some tissues of three species of marine turtles stranded along the French Atlantic coasts
}

Florence Caurant, Paco Bustamante, Monique Bordes, Pierre Miramand

\section{- To cite this version:}

Florence Caurant, Paco Bustamante, Monique Bordes, Pierre Miramand. Bioaccumulation of cadmium, copper and zinc in some tissues of three species of marine turtles stranded along the French Atlantic coasts. Marine Pollution Bulletin, 1999, 38 (12), pp.1085-1091. 10.1016/S0025-326X(99)001095. hal-00922297

\section{HAL Id: hal-00922297 \\ https://hal.science/hal-00922297}

Submitted on 25 Dec 2013

HAL is a multi-disciplinary open access archive for the deposit and dissemination of scientific research documents, whether they are published or not. The documents may come from teaching and research institutions in France or abroad, or from public or private research centers.
L'archive ouverte pluridisciplinaire HAL, est destinée au dépôt et à la diffusion de documents scientifiques de niveau recherche, publiés ou non, émanant des établissements d'enseignement et de recherche français ou étrangers, des laboratoires publics ou privés. 
Bioaccumulation of cadmium, copper and zinc in some tissues of three species of marine turtles stranded along the French Atlantic coasts

Caurant Florence*, Bustamante Paco, Bordes Monique, Miramand Pierre

Laboratoire de Biologie et Environnement Marins, Université de La Rochelle, rue de Vaux de Foletier, 17026 La Rochelle Cedex, France

* Corresponding author: Tel.: +33-5-46-50-02-91; fax: +33-5-46-45-82-64; e-mail: fcaurant@univ-lr.fr 
Abstract: Cadmium, copper and zinc have been analysed in some tissues and organs of Loggerhead, Kemp's Ridley (only muscle for this species) and Leatherback turtles stranded along the Atlantic coasts of France. The pancreas analysed only in Leatherback turtles exhibited the highest metal concentrations, which is very surprising for an organ which does not play a role in the detoxification processes. The distribution of these elements in kidney, liver and muscle were quite similar to that found in marine mammals or seabirds. Nevertheless, mean cadmium concentrations in the kidney were as high as $13.3 \mu \mathrm{g} \mathrm{g}^{-1}$ wet weight in the Loggerhead turtles and $30.3 \mu \mathrm{g} \mathrm{g}^{-1}$ wet weight in the Leatherback turtles. Such high concentrations in the Leatherback turtles have never been recorded before. The main source of cadmium for marine turtles is probably the food. The Leatherback turtles are known to feed mainly on jellyfish in this area. Ten times higher cadmium concentrations have been determined in jellyfish compared to fish. This would imply a greater exposure to cadmium for Leatherback turtles, which probably need to eat great quantities of jellyfish to cover their needs.

Keywords: cadmium; copper; zinc; bioaccumulation; sea turtles; Atlantic coasts of France. 


\section{Introduction}

Sea turtles like marine mammals and seabirds have a long lifespan and occupy high trophic levels in the marine food web. Nevertheless, if numerous studies have been carried out on both last species showing their utility as biological indicators of chemical pollution (reviewed in Wagemann and Muir, 1984; Walsh, 1990; Furness, 1993; Aguilar and Borrell, 1997), studies on heavy metals or organic compounds bioaccumulation in sea turtles are very limited and use eggs more often than tissues and organs (Stoneburner et al., 1980; Sakai et al., 1995; Vazquez et al., 1997). However, besides all the human activities involving mortality in sea turtles, that is consumption of meat, degradation of nesting beaches and feeding habitats, impact of fishing and shellfishing industries..., sea turtles are also probably affected by marine pollutants and there is a need for monitoring chemical pollutants in an effort to conserve their populations (Sakai et al., 1995).

Five species of marine turtles have been recorded in the French Atlantic waters: the leatherback turtle Dermochelys coriacea, the green turtle Chelonia mydas, the loggerhead turtle Caretta caretta, the hawksbill turtle Eretmochelys imbricata and the Kemp's Ridley turtle Lepidochelys kempii. The leatherback turtle is frequently observed along the French Atlantic coasts especially in summer, with a maximum of records in the "Pertuis charentais" (Fig. 1). Leatherback turtles are known to travel thousands of miles annually around the ocean basins of the world and the origin of these individuals could be the French Guiana where is located the most important stock of the species in the world (Duguy, 1983). In 1995, a leatherback turtle ringed in French Guiana has been caught accidentally in the French waters and has confirmed this migration.

The individuals of loggerhead and Kemp's Ridley turtles found along the French Atlantic coasts are all juveniles as most of the specimens found in northern Europe. Brongersma (1972) suggested that these juvenile turtles are most probably carried from the Western Atlantic on the Gulf Stream and North Atlantic Current.

The purpose of this study was to assess the presence of cadmium, a toxic metal relatively abundant in the Gironde estuary (south limit of the "Pertuis charentais", see Fig. 1) (Boutier et al., 1989), copper and zinc in different tissues of turtles stranded along these coasts. 


\section{Materials and methods}

\subsection{Samples}

Tissues samples (pectoral muscle, kidney and liver) from leatherback, loggerhead and Kemp's Ridley turtles have been collected from stranded specimens for this study. For two specimens of loggerhead and two specimens of leatherback turtles, numerous organs and tissues including heart, spleen, intestine, lungs and bladder have been sampled in addition to muscle, kidney and liver. The biometry of the individuals and the details of the sampling are shown in Table 1 . All samples were stored at $-20^{\circ} \mathrm{C}$ until chemical analysis.

\subsection{Analytical procedure}

Tissue samples were dried for several days at $60^{\circ} \mathrm{C}$ to constant weight. Tissues and organs were analysed for cadmium $(\mathrm{Cd})$, copper $(\mathrm{Cu})$ and zinc $(\mathrm{Zn})$. Two aliquots of approx. 200 or $300 \mathrm{mg}$ of each homogenized dry sample were heated with a mixture of $5 \mathrm{ml}$ of suprapure $65 \%$ nitric acid and $200 \mu \mathrm{l}$ of supra-pure $70 \%$ perchloric acid at $80^{\circ} \mathrm{C}$ until the solution was clear. After evaporation, the residues were dissolved in $10 \mathrm{ml}$ of $0.3 \mathrm{~N}$ supra-pure nitric acid. $\mathrm{Cd}, \mathrm{Cu}$ and $\mathrm{Zn}$ were determined by Flame Atomic Absorption Spectrophotometry (AAS) with a Varian spectrophotometer Spectra 250 Plus with deuteriun background correction. Concentrations are expressed in $\mu \mathrm{g} \mathrm{g}^{-1}$ wet weight. As analytical quality control, standards of the NRC Canada (dogfish liver DOLT-2) were analysed using the same procedure. Our results were in good agreement with the certified values. Measurements were also validated by the IAEA Intercalibration Exercise (Coquery et al., 1997).

\section{Results}

\subsection{Organotropism}

Cadmium, copper and zinc concentrations in different organs of two loggerhead and two leatherback turtles are shown in Figs. 2 and 3. Pancreas has been analysed only in the leatherback turtles and exhibited the highest concentrations in the case of the three elements. Concentrations were always much higher than in the other organs with $68.8 \mu \mathrm{g} \mathrm{Cd} \mathrm{g}^{-1}, 23.2$ $\mu \mathrm{g} \mathrm{Cu} \mathrm{g}^{-1}$ and $142.3 \mu \mathrm{g} \mathrm{Zn} \mathrm{g}^{-1}$. In both species, kidney and liver exhibited high cadmium and copper concentrations: 20.5 and $7.72 \mu \mathrm{g} \mathrm{g}^{-1}$ for cadmium in the kidney in leatherback and loggerhead turtles, respectively; 2.65 and $2.29 \mu \mathrm{g} \mathrm{g}^{-1}$ for copper in the kidney in leatherback 
and loggerhead turtles, respectively; 8.4 and $1.22 \mu \mathrm{g} \mathrm{g}^{-1}$ for cadmium in the liver in leatherback and loggerhead turtles, respectively; 5.84 and $4.14 \mu \mathrm{g} \mathrm{g}^{-1}$ for copper in the liver in leatherback and loggerhead turtles, respectively. On the other hand, the spleen accumulated cadmium in a different proportion in both species. It was the second organ for cadmium accumulation in the loggerhead turtle after the kidney and only the fifth one in the leatherback turtles with concentration much lower than in the kidney and the liver.

Concerning zinc, except the cases of the pancreas in the leatherback turtles and the carapace in the loggerhead turtles, the concentrations were relatively homogeneous in the organs. In both species, heart exhibited the highest concentrations.

Bioaccumulation in all individuals

Muscle, liver and kidney are the tissues which have been analysed in nearly all the stranded individuals and metal concentrations are compared with other studies. Heavy metal concentrations in the muscle, liver and kidney of turtles are shown in Table 2.

The variability of the coefficients of variation reflected the individual variations typical of each element. Zn exhibited the lowest coefficients of variation (contained between $14 \%$ and $38 \%$ ). It is an essential element for which the individual variations are known to be limited as a consequence of homeostasis processes. Nevertheless $\mathrm{Cu}$, which is also an essential element, exhibited higher coefficients of variation than $\mathrm{Zn}$, contained between $12.3 \%$ and $79.6 \%$. The highest coefficients of variation were observed for $\mathrm{Cd}$ (contained between $57.1 \%$ and $159.7 \%$ ), which is a toxic element. In loggerhead and leatherback turtles, kidney tissue exhibited the highest $\mathrm{Cd}$ concentrations whereas liver tissue exhibited the highest $\mathrm{Cu}$ concentrations. The most streaking feature of this study was the high $\mathrm{Cd}$ concentrations encountered in the leatherback turtles. In the three tissues including muscle, $\mathrm{Cd}$ concentrations were much higher in this species than in the loggerhead and Kemp's Ridley turtles.

\section{Discussion}

Similar distribution patterns of $\mathrm{Cd}$ and $\mathrm{Cu}$ have been reported in marine mammals or seabirds (Honda et al., 1983; Wagemann and Muir, 1984; Wagemann et al., 1990; Furness, 1993; Caurant et al., 1994; Wenzel et al., 1996; Debacker et al., 1997), but the ratio between $\mathrm{Cd}$ in kidney and $\mathrm{Cd}$ in liver was much higher in turtles than in marine mammals or seabirds. 
Zinc concentrations in turtles were quite homogenous in the different tissues, compared to mammals. This would suggest a slight different organotropism of these trace elements in turtles compared to seabirds or marine mammals.

The pancreas exhibited high metal concentrations which have never been previously reported in marine vertebrates. This organ has been analysed in a study carried out by André et al. (1990) about cadmium contamination of tissues of a delphinid species Stenella attenuata. Cd average concentration was $5.64 \mu \mathrm{g} \mathrm{g}^{-1}$, much lower than in kidney $\left(48.7 \mu \mathrm{g} \mathrm{g}^{-1}\right)$ or liver $\left(8.7 \mu \mathrm{g} \mathrm{g}^{-1}\right)$. Nevertheless, in humans, cadmium is known to accumulate in the pancreas which can exhibit higher concentrations than in the liver because of a faster elimination in this last organ (Lauwerys, 1990).

Our data have been compared with loggerhead turtles from Japan (Sakai et al, 1995) and from the Adriatic Sea (Storelli et al., 1998), and green turtles from the Hawaiian Islands (Aguirre et al., 1994). $\mathrm{Cu}$ concentrations in the liver of green turtles were much higher than those of loggerhead and leatherback turtles, whereas they were comparable between the species in muscle and kidney. Again zinc concentrations were quite homogenous between species in the three organs (Tables 2 and 3). Although $\mathrm{Cd}$ concentrations exhibited a great individual variability, the mean concentrations were high in all the species, especially in the kidney (Tables 2 and 3), which appears to contain the highest levels. Nevertheless, concerning the leatherback turtle, the concentrations reported in a single individual killed in a net in Cardigan Bay (UK) were considerably lower than the concentrations found in our study (Table 3). Cd concentrations were outstandingly higher in the three organs of loggerhead and especially leatherback turtles of our study than in mammals of the same area. The mean $\mathrm{Cd}$ concentrations in 19 common dolphins (Delphinus delphis), stranded along the French Atlantic coasts were respectively $1.2 \pm 1.58 \mu \mathrm{g} \mathrm{g}^{-1}$ wet weight in the liver, $4.18 \pm 4.31 \mu \mathrm{g} \mathrm{g}^{-1}$ wet weight in the kidney and $0.02 \pm 0.02 \mu \mathrm{g} \mathrm{g}^{-1}$ wet weight in the muscle (Caurant, unpublished data). Except in the case of Davenport and Wrench's study, the high Cd concentrations seem to be a common point in the three species of turtles studied whatever their origin was (Table $3)$.

Different ecological and biological factors control concentrations of trace elements in vertebrates. The age is known to be one of them, especially for toxic elements such as $\mathrm{Cd}$ whose concentrations are generally low at birth and accumulate with age. Skeletochronology the use of incremental growth marks in the humerus to estimate age - has been used in several studies to assign ages to sea turtles (Zug et al., 1995; Parham and Zug, 1997). Nevertheless, this technique has recently been criticized by Bjorndal et al. (1998), who underline that the 
two assumptions upon with this technique is based: (1) growth marks in the humerus of sea turtles are laid annually; (2) there is a constant proportional allometry between radial growth of the humerus and longitudinal growth of the carapace-must be validated before being applied. Moreover, growth rates of turtles are quite variable within the same cohort and populations (Zug et al., 1995) and depend on the temperature, the food and are also probably different between wild or captive animals. Thus, there is a great difficulty in comparing bioaccumulation of trace elements in turtles from different areas. Nevertheless $\mathrm{Cd}$ concentrations in this study seem all the more high since the loggerhead and Kemp's Ridley turtles are small juvenile individuals and loggerhead turtles for example can take 20-63 years to reach sexual maturity and live for 50 to more than 100 years (Parham and Zug, 1997). Concerning the leatherback turtles, a study about the nesting of this species in French Guiana has allowed to measure 834 females (Fretey, 1979). The mean straight-line carapace length was $1.67 \mathrm{~m}$ with a minimum of $1.35 \mathrm{~m}$ and a maximum of $1.89 \mathrm{~m}$ and the sexual maturity would be reached at $1.35 \mathrm{~m}$. According this study, the specimens of our samples are mature individuals (Table 1) but no data allow to determine their age.

Food is probably the main source of exposure to heavy metals and other trace elements for marine vertebrates. In marine mammals or seabirds, such concentrations (and also much higher) are often encountered in animals feeding mainly on cephalopods which are known to accumulate $\mathrm{Cd}$ in higher levels than fish and are considered to be an important vector of this element to top marine predators (Bustamante et al., 1998). Hatchling appears to be nearly omnivorous but the diets of adults are more specialized and differ among species- leatherback turtles feed on jellyfish and loggerhead turtles are mostly carnivorous (Bowen and Avise, 1995). A study carried out by Godley et al. (1997) suggests that loggerhead turtles in the eastern Mediterranean Sea do indeed feed upon benthic molluscs and crustacea, at shallow to moderate depths, from both rocky and sedimentary habitats. For both post-pelagic juveniles and adults of these species, study of prey items in other regions of the world have found the diet to be dominated by benthic molluscs, crustaceans and coelenterates (Godley et al., 1997). Although such a study has not been done on the stranded individuals of this study, the postmortem examinations very often revealed plastic fragments mixed with benthic preys in the stomach (Duguy et al., 1998). These food items are not very specific and the high Cd concentrations found in sea turtles could also be the consequence of the metabolism or physiology of these species which would lead to a great accumulation of this element.

In temperate latitudes, the leatherback turtle is associated with swarms or jellyfish such as Rhizostoma or Cyanea (Davenport and Wrench, 1990). In the "Pertuis charentais" 
Rhizostoma pulmo is present in great quantities and the leatherback turtles have often been observed feeding on this species, and ingesting up to 10 individuals per day (Duron-Dufrenne, 1978; Duguy, 1983). This species is probably the unique air breathing vertebrate feeding mainly upon medusea. This constitutes a food chain which is very poorly studied and that difficulty explains such high Cd concentrations found in the liver and the kidney tissues of the species. Cd has been analysed in one jellyfish caught in the "Pertuis charentais". The concentration was $0.27 \mu \mathrm{g} \mathrm{g}^{-1}$ dry weight, which is of the same order as the concentrations found in the plankton in this area $\left(1.14 \mu \mathrm{g} \mathrm{g}^{-1}\right.$ dry weight in the microzooplankton, 0.2 in the Mysidacae and 0.5 in the copepods, unpublished data), but 10 times higher than in fish. Moreover the energy metabolism of the leatherback turtles is unknown, but the energetic value of the jellyfish is probably very low. Thus the turtles would have to ingest a great quantity of jellyfish to cover their needs and this could imply a high exposure to $\mathrm{Cd}$ for the leatherback turtles, at least higher than for fish-eating vertebrates like some coastal dolphins.

Turtles are certainly very long-lived animals and would therefore appear to be very good indicators of the degree of contamination of the oceanic food web. However the data on concentrations of heavy metals in these species appear to be very difficult to interpret because the lack of information on the age of the individuals, especially in the case of leatherback turtles, and because generally too few individuals have been analysed to evaluate the bioaccumulation with age. In the future, the analysis of individuals coming from the French Guiana could allow to evaluate and discriminate the importance of age and food in the bioaccumulation of metals.

Acknowledgements: We are grateful to R. Duguy, P. Morinière and A. Meunier from the Aquarium of la Rochelle, for their precious help in the collection and transmission of the samples. We are grateful to Olivier Van Canneyt, Karine Le Coq and Eric Poncelet from the "Centre de Recherche des Mammifères Marins" of La Rochelle for the collection of jellyfish.

\section{References}

Aguilar, A. and Borrell, A. (1997) Marine Mammals and Pollution, an Annoted Bibliography. Fundacio Desenvolupament Sostenible, Barcelona, Spain. 
Aguirre, A.A., Balazs, G.H., Zimmerman, B. and Galey, F.D. (1994) Organic contaminants and trace metals in the tissues of green turtles (Chelonia mydas) afflicted with fibropapillomas in the Hawaiian Islands. Marine Pollution Bulletin 28, 109-114.

André, J. M., Amiard, J.C., Amiard-Triquet, C., Boudou, A. and Ribeyre, F. (1990) Cadmium contamination of tissues and organs of delphinids species (Stenella attenuata) - influence of biological and ecological factors. Ecotoxicology and Environmental Safety 20, 290-306.

Bjorndal, K.A., Bolten, A.B., Bennet, R. A., Jacobson, E.R., Wronski, T.J., Valeski, J.J. and Eliazar, P.J. (1998) Age and growth in sea turtles: limitations of skeletochronology for demographic studies. Copeia 1, 23-30.

Boutier, B., Chiffoleau, J.F., Jouanneau, J.M., Latouche, C. and Phillips, I. (1989) La contamination de la Gironde par le cadmium: origine, extension, importance. Rapports scientifiques et techniques de l'IFREMER, Plouzané 14, 105p.

Bowen, B.W. and Avise, J.C. (1995) Conservation genetics of marine turtles. In Conservation genetics: case histories from nature eds. J. C. avise and J. L. Hamrick, pp. 190-237. Chapman \& Hall, New York.

Brongersma, L.D. (1972) European Atlantic turtles. Zoological Verhandel., Leiden 121, 1318.

Bustamante, P., Caurant, F., Fowler, S.W. and Miramand, P. (1998) Cephalopods as a vector for the transfer of cadmium to top marine predators in the north-east Atlantic Ocean. Science Total Environment 220, 71-80.

Caurant, F., Amiard, J.C., Amiard-Triquet, C. and Sauriau, P.G. (1994) Ecological and biological factors controlling the concentrations of trace elements ( $\mathrm{As}, \mathrm{Cd}, \mathrm{Cu}, \mathrm{Hg}, \mathrm{Se}, \mathrm{Zn}$ ) in delphinids Globicephala melas from the North Atlantic Ocean. Marine Ecology Progress Series 103, 207-219.

Coquery, M., Carvalho, F.P., Harvat, M. and Azemard, S. (1997) World-wide intercomparison exercise for the determination of trace elements in Fucus samples. IAEA 140, IAEA/AL 1139, report 64, IAEA, Vienna, p. 93.

Davenport, J. and Wrench, J. (1990) Metal levels in a leatherback turtle. Marine Pollution Bulletin 21, 40-41.

Debacker, V., Holsbeek, L., Tapia, G., Gobert, S., Joiris, C.R., Jauniaux, T., Coignoul, F. and Bouquegneau, J.M. (1997) Ecotoxicological and pathological studies of common guillemots Uria algae veached on the Belgian coast during six successive wintering periods (1989-90 to 1994-95). Diseases of Aquatic Organisms 29, 159-168. 
Duguy, R. (1983) La tortue luth (Dermochelys coriacea) sur les côtes de France. Annales de la Société Naturelle de Charente Maritime, suppl. Duguy, R., Morini_ere, P. and Meunier, A. (1998) Observations de tortues marines en 1997 (Atlantique) Annales de la Société Naturelle de Charente Maritime VIII (7), 760-779.

Duron-Dufrenne, M. (1978) Contribution à l'étude de la biologie de Dermochelys coriacea L. dans les Pertuis charentais. Thesis, University of Bordeaux.

Fretey, J. (1979) Mensurations de tortues luths femelles adultes, Dermochelys coriacea (Linné), en Guyanne française. Bulletin de la Société Herpétologique de France 11, 518523.

Furness, R.W., (1993) Birds as monitors of pollutants. In Birds as Monitors of Environmental Change, eds. R.W. Furness and J. J. D. Greenwood, pp. 86-143. Chapman \& Hall, London, Glasgow, New York, Tokyo, Melbourne, Madras.

Godley, B.J., Smith, S.M., Clark, P.F. and Taylor, J.D. (1997) Molluscan and crustacean items in the diet of the loggerhead turtle, Caretta caretta (Linnaeus, 1758) Testudines: Chelonidae in the eastern Mediterranean. Journal of Molluscan Studies 63, 474-476.

Honda, K., Tatsukawa, R., Itano, K., Miyazaki, N. and Fijiyama, T. (1983) Heavy metal concentrations in muscle, liver and kidney tissue of striped dolphin, Stenella coeruleoalba, and their various with body length, weight, age and sex. Agricultural and Biological Chemistry 47, 1219-1228.

Lauwerys, R., (1990) Cadmium. In Toxicologie Industrielle et Intoxication Professionnelle. ed. R.R. Lauwerys, pp. 136-149. Masson, Paris.

Parham, J.F., and Zug, G.R., (1997) Age and growth of loggerhead sea turtles (Caretta caretta) of coastal Georgia: an assessment of skeletochronological age-estimates. Bulletin of the Marine Science 61, 287-304.

Sakai, H., Ichihashi, H., Suganuma, H. and Tatsukawa, R. (1995) Heavy metal monitoring in sea turtles using eggs. Marine Pollution Bulletin 30, 347-353.

Stoneburner, D.L., Nicora, M.N. and Blood, E.R. (1980) Heavy metals in loggerhead sea turtle eggs (Caretta caretta): evidence to support the hypothesis that demes exist in the western Atlantic population. Journal of Herpetology 14, 171-175.

Storelli, M.M., Ceci, E. and Marcotrigiano, G.O. (1998) Distribution of heavy metal residues in some tissues of Caretta caretta (Linnaeus) specimen beached along the Adriatic Sea (Italy). Bulletin of the Environmental and Contamination Toxicology 60, 546-552.

Vazquez, G.F., Reyes, M.C., Fernandez, G., Aguayo, J.E.C. and Sharma, V.K. (1997) Contamination in marine turtle (Dermochelys coriacea) egg shells of Playon de 
Mexiquillo, Michoacan, Mexico. Bulletin of the Environmental and Contamination Toxicology 58, 326-333.

Wagemann, R. and Muir D.C.G. (1984) Concentrations of heavy metals and organochlorines in marine mammals of northern waters: overview and evaluation. Canadian Technical Report of the Fisheries and Aquatic Science 1279, 97.

Wagemann, R., Stewart, R.E.A., Béland, P. and Desjardins, C. (1990) Heavy metals and selenium in tissues of beluga whales, Delphinapterus leucas, from the Canadian Arctic and the St. Lawrence estuary. In Advances in research on the Beluga Whale, Delphinapterus leucas eds. T. G. Smith, D. J. St. Aubin and J. R. Geraci, Canadian Bulletin of the Fisheries and Aquatic Science 224, 191-206.

Walsh, P.M. (1990) The use of seabirds as monitors of heavy metals in the marine environment. In Heavy metals in the marine environment eds. R. W. Furness and P. S. Rainbow, pp. 183-204. CRC Press, London.

Wenzel, C. and Adelung, D. (1996) The suitability of oiled guillemots (Uria algae) as monitoring organisms for geographical comparisons of trace element contaminants. Archives of the Environmental and Contamination Toxicology 31, 368-377.

Zug, G.R., Balazs, G.H. and Wetherall, J.A. (1995) Growth in juvenile loggerhead seaturtles (Caretta caretta) in the North Pacific pelagic habitat. Copeia 2, 484-487. 


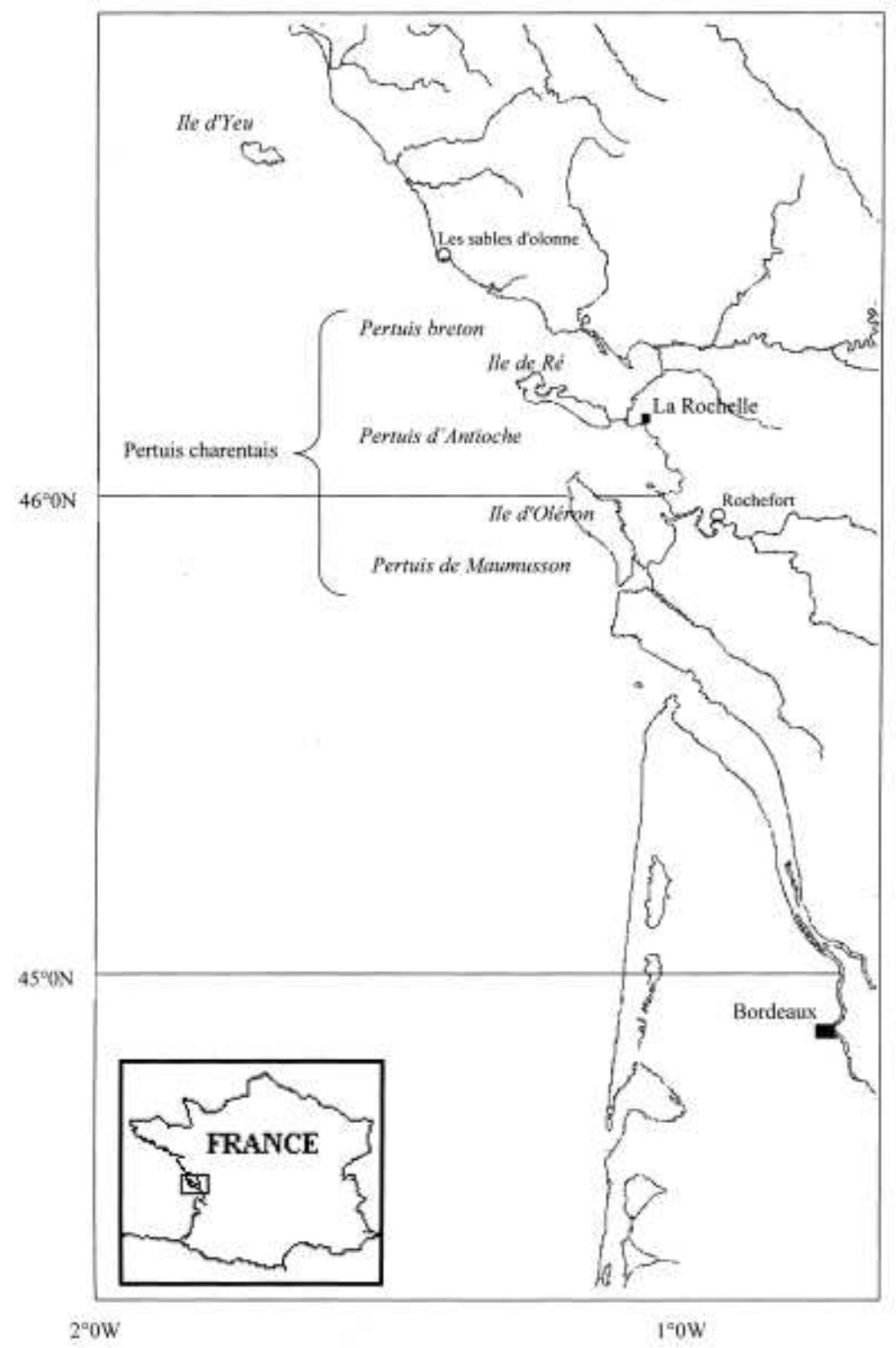

Fig. 1. Localization of all the "Pertuis Charentais": the area of the stranded sea turtles. 


\section{Cd in $\mu \mathrm{g} \cdot \mathrm{g}^{-1}$ wet weight}

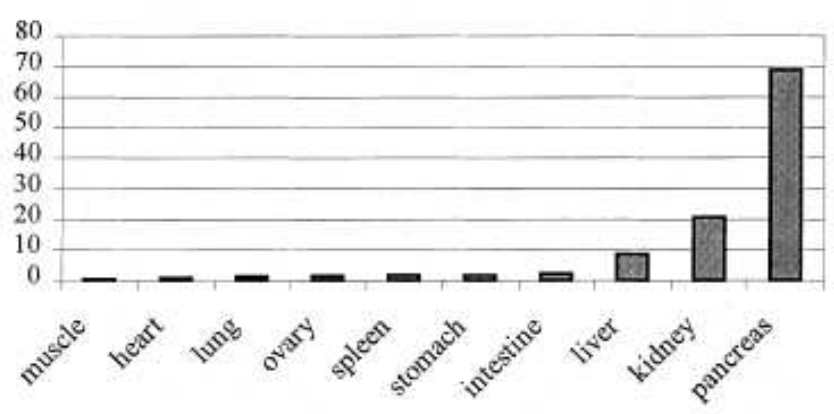

\section{$\mathrm{Cu}$ in $\mu \mathrm{g} \cdot \mathrm{g}^{-1}$ wet weight}

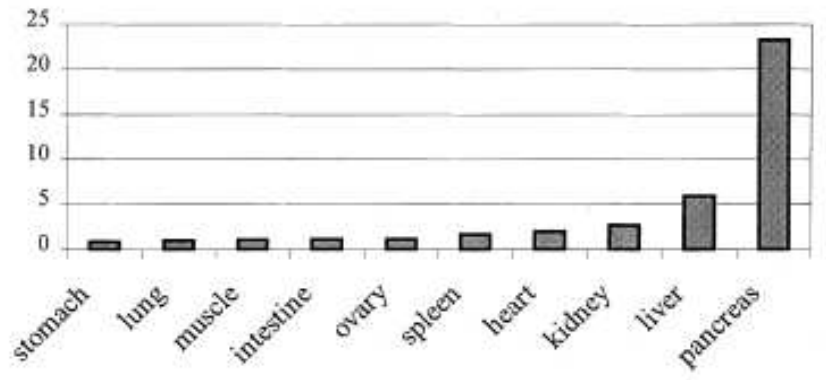

$\mathrm{Zn}$ in $\mu \mathrm{g} . \mathrm{g}^{-1}$ wet weight

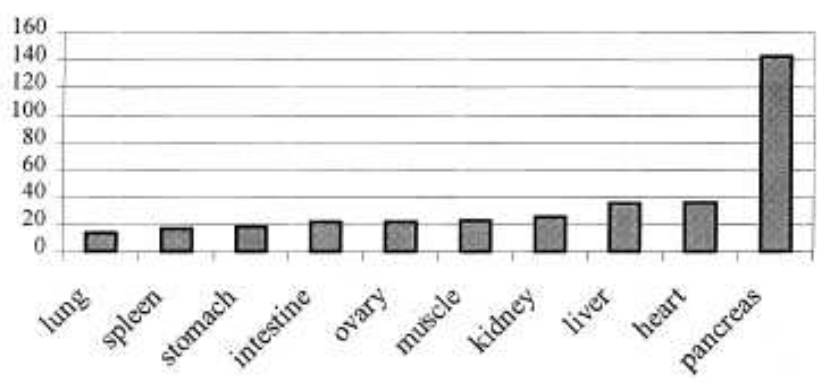

Fig. 2. Distribution of cadmium, copper and zinc concentrations (in $\mu \mathrm{g} \mathrm{g}^{-1}$ wet weight) in some organs and tissues of two individuals of leatherback turtle stranded along the French Atlantic coasts. 
Cd in $\mu \mathrm{g} \cdot \mathrm{g}^{-1}$ wet weight

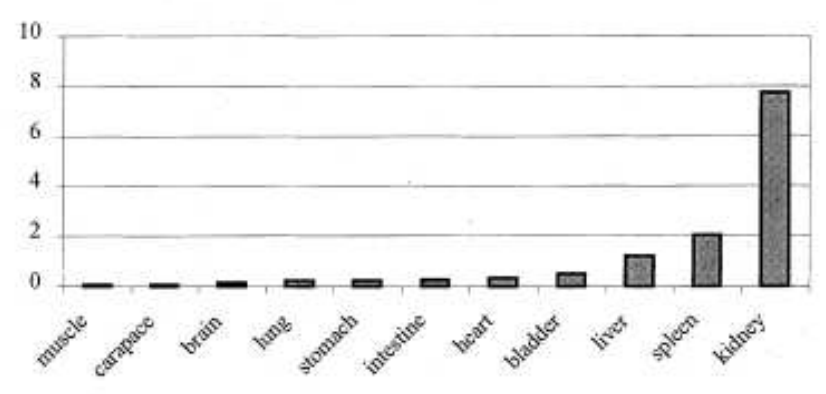

$\mathrm{Cu}$ in $\mu \mathrm{g} \cdot \mathrm{g}^{-1}$ wet weight

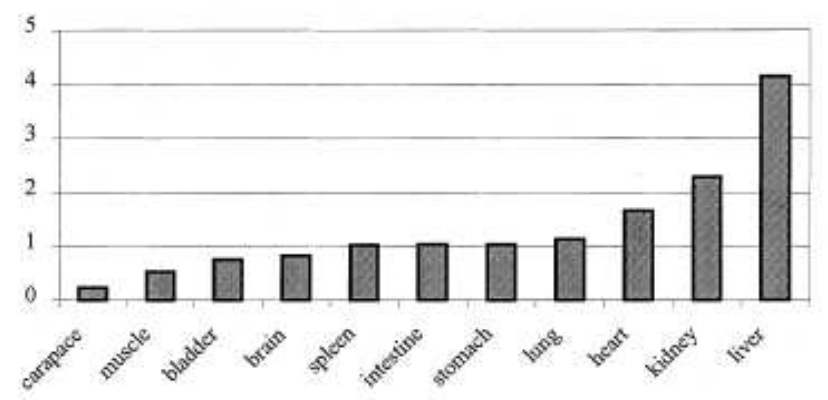

$\mathrm{Zn}$ in $\mu \mathrm{g} \cdot \mathrm{g}^{-1}$ wet weight

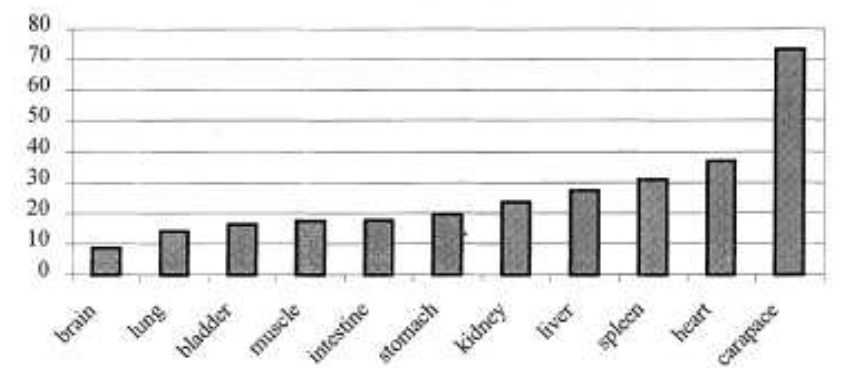

Fig. 3. Distribution of cadmium, copper and zinc concentrations (in $\mu g^{-1}$ wet weight) in some organs and tissues of two individuals of loggerhead turtle stranded along the French Atlantic coasts. 
Table 1. Size $(\mathrm{cm})$ and weight $(\mathrm{kg})$ of loggerhead, leatherback and kemp's Ridley turtles, stranded on the Atlantic coasts of France (SCL: Standard Carapace Length).

\begin{tabular}{lcc}
\hline & SCL & Weight \\
\hline $\begin{array}{l}\text { Caretta caretta } \\
\text { (Loggerhead turtle, } n=21 \text { ) }\end{array}$ & & \\
$\quad$ Mean & $29.4 \pm 15.3$ & $2.8 \pm 2.2$ \\
$\quad$ Min-max & $21.3-34.5$ & $0.3-7.5$ \\
$\begin{array}{l}\text { Lepidochelys kempii } \\
\text { Kemp's Ridley turtle, } n=6)\end{array}$ & & \\
$\quad$ Mean & $25.8 \pm 5.2$ & $2.5 \pm 1.5$ \\
$\quad$ Min-max & $21.3-34.5$ & $1.4-5.2$ \\
Dermochelys coriacea & & \\
(Leatherback turtle, $n=16)$ & & - \\
$\quad$ Mean & $145.7 \pm 22.6$ & - \\
$\quad$ Min-max & $115-188$ & - \\
\hline
\end{tabular}


Table 2. Heavy metal concentrations $\left(\mu \mathrm{g} \mathrm{g}^{-1}\right.$ wet weight, mean \pm standard deviation, minmax) in tissues of Loggerhead, Leatherback and Kemp's Ridley turtles from the Atlantic coasts of France.

\begin{tabular}{|c|c|c|c|}
\hline & $\mathrm{Cd}$ & $\mathrm{Cu}$ & $\mathrm{Zn}$ \\
\hline \multicolumn{4}{|l|}{ Liver } \\
\hline \multicolumn{4}{|c|}{ Loggerhead turtle $(n=7)$} \\
\hline Mean & $2.58 \pm 4.12$ & $8.25 \pm 6.59$ & $25.0 \pm 9.5$ \\
\hline Min-max & $0.30-11.8$ & $2.32-20.9$ & $14.5-38.4$ \\
\hline \multicolumn{4}{|c|}{ Leatherback turtle $(n=18)$} \\
\hline Mean & $6.84 \pm 3.66$ & $8.61 \pm 4.40$ & $29.2 \pm 4.1$ \\
\hline Min-max & $0.60-14.7$ & $1.05-19.7$ & $21.9-36.5$ \\
\hline \multicolumn{4}{|l|}{ Kidney } \\
\hline \multicolumn{4}{|c|}{ Loggerhead turtle $(n=5)$} \\
\hline Mean & $13.3 \pm 13.6$ & $2.21 \pm 0.46$ & $23.6 \pm 6.9$ \\
\hline Min $-\max$ & $1.68-35.7$ & $1.76-2.83$ & $16.5-33.8$ \\
\hline \multicolumn{4}{|c|}{ Leatherback turtle $(n=5)$} \\
\hline Mean & $30.3 \pm 28.1$ & $2.68 \pm 0.33$ & $25.7 \pm 7.7$ \\
\hline Min-max & $8.47-62.0$ & $2.36-3.02$ & $18.5-33.8$ \\
\hline \multicolumn{4}{|l|}{ Muscle } \\
\hline \multicolumn{4}{|c|}{ Loggerhead turtle $(n=21)$} \\
\hline Mean & $0.08 \pm 0.05$ & $0.73 \pm 0.45$ & $19.6 \pm 5.7$ \\
\hline Min-max & $0.004-0.18$ & $0.34-2.23$ & $12.2-36.3$ \\
\hline \multicolumn{4}{|c|}{ Leatherback turtle $(n=16)$} \\
\hline Mean & $0.35 \pm 0.20$ & $0.95 \pm 0.49$ & $25.9 \pm 5.9$ \\
\hline Min-max & $0.16-1.00$ & $0.40-2.56$ & $18.3-37.3$ \\
\hline \multicolumn{4}{|c|}{ Kemp's Ridley turtle $(n=6)$} \\
\hline Mean & $0.09 \pm 0.09$ & $0.98 \pm 0.50$ & $16.4 \pm 3.3$ \\
\hline Min $-\max$ & $0.01-0.26$ & $0.44-1.85$ & $13.3-20.5$ \\
\hline
\end{tabular}


Table 3. Heavy metal concentrations ( $\mu \mathrm{g} \mathrm{g}^{-1}$ wet weight, mean \pm standard deviation, minmax) in tissues of different turtles species from different areas (NA: Not Analysed).

\begin{tabular}{|c|c|c|c|c|c|}
\hline & $\mathrm{Cd}$ & $\mathrm{Cu}$ & $\mathrm{Zn}$ & Origin & Reference \\
\hline \multicolumn{6}{|l|}{ Liver } \\
\hline \multicolumn{6}{|l|}{ Loggerhead turtle $(n=7)$} \\
\hline Mean & $9.29 \pm 3.3$ & $17.9 \pm 8.17$ & $27.9 \pm 10.4$ & Japan & Sakai et al. (1995) \\
\hline Min-max & $5.66-14.6$ & $6.47-33.9$ & $24.2-35.1$ & & \\
\hline \multicolumn{6}{|l|}{ Loggerhead turtle $(n=12)$} \\
\hline Mean & $2.24 \pm 1.78$ & NA & NA & Adriatic Sea & Storelli et al. (1998) \\
\hline Min-max & $0.78-5.97$ & & & & \\
\hline \multicolumn{6}{|l|}{ Green turtle $(n=13)$} \\
\hline Mean & $9.30 \pm 8.58$ & $87.6 \pm 61.7$ & $30.6 \pm 10.4$ & Hawaiian Islands & Aguirre et al. (1994) \\
\hline Min-max & $0.39-26.0$ & $1.30-189$ & $15.1-45.8$ & & \\
\hline Leatherback turtle $(n=1)$ & $0.22^{\mathrm{a}}$ & $0.15 \pm 0.04^{\mathrm{a}}$ & $2.62 \pm 0.15^{\mathrm{a}}$ & British Island & Davenport and Wrench (1990) \\
\hline \multicolumn{6}{|l|}{ Kidney } \\
\hline \multicolumn{6}{|l|}{ Loggerhead turtle $(n=7)$} \\
\hline Mean & $39.4 \pm 16.2$ & $1.30 \pm 0.20$ & $25.8 \pm 4.17$ & Japan & Sakai et al. (1995) \\
\hline Min-max & $18.1-56.5$ & $0.99-1.56$ & $19.2-30.4$ & & \\
\hline \multicolumn{6}{|l|}{ Loggerhead turtle $(n=12)$} \\
\hline Mean & $7.52 \pm 6.65$ & NA & NA & Adriatic Sea & Storelli et al. (1998) \\
\hline Min-max & $0.12-19.9$ & & & & \\
\hline \multicolumn{6}{|l|}{ Green turtle $(n=12)$} \\
\hline Mean & $26.0 \pm 20.2$ & $3.60 \pm 2.60$ & $22.3 \pm 7.2$ & Hawaiian Islands & Aguirre et al. (1994) \\
\hline Min-max & $4.77-70.2$ & $1.10-10.5$ & $12.5-38.1$ & & \\
\hline \multicolumn{6}{|l|}{ Muscle } \\
\hline \multicolumn{6}{|l|}{ Loggerhead turtle $(n=7)$} \\
\hline Mean & $0.062 \pm 0.026$ & $0.83 \pm 0.26$ & $24.2 \pm 3.80$ & Japan & Sakai et al. (1995) \\
\hline Min-max & $0.041-0.117$ & $0.531-1.28$ & $19.5-31.0$ & & \\
\hline \multicolumn{6}{|l|}{ Loggerhead turtle $(n=12)$} \\
\hline Mean & $0.14 \pm 0.16$ & NA & NA & Adriatic Sea & Storelli et al. (1998) \\
\hline Min-max & $0.023-0.55$ & & & & \\
\hline Leatherback turtle $(n=1)$ & $0.06^{\mathrm{a}}$ & $0.26^{\mathrm{a}}$ & $1.89^{\mathrm{a}}$ & British Island & Davenport and Wrench (1990) \\
\hline
\end{tabular}

${ }^{\mathrm{a}} \mu \mathrm{g} \mathrm{g} \mathrm{g}^{-1}$ dry weight. 